\title{
Flexural behaviour and punching shear of self- compacting concrete ribbed slab reinforced with steel fibres
}

\author{
Hazrina Ahmad ${ }^{1}$, Mohd Hisbany Mohd Hashim ${ }^{1 *}$, Afidah Abu Bakar ${ }^{1}$ and Siti Hawa \\ Hamzah $^{1}$ \\ ${ }^{1}$ Faculty of Civil Engineering, Universiti Teknologi MARA, 40450 Shah Alam, Malaysia
}

\begin{abstract}
This paper investigates the effects of steel fibres as a replacement to the conventional reinforcement under flexural behaviour and punching shear in self-compacting (SCC) ribbed slab reinforced with steel fibres. Four ribbed slabs with similar dimensions of $2.8 \mathrm{~m}$ length $\mathrm{x}$ $1.2 \mathrm{~m}$ width and $0.2 \mathrm{~m}$ thickness were constructed. Two of the samples were considered as control samples (conventionally reinforced with reinforcement bars and welded mesh) while another two samples were fully reinforced with $1 \%\left(80 \mathrm{~kg} / \mathrm{m}^{3}\right)$ volume of steel fibres incorporated to the SCC mix. For the flexural behaviour study, the ribbed slab samples were subjected to two line loads under four point bending. Meanwhile, for the punching shear analysis, the ribbed slab samples were subjected to a point load to simulate loading from the column. The analysis of the experimental results displayed that steel fibres incorporation had been found to effectively delay the first crack occurrence under both flexural and punching shear. The steel fibre replacement has been proven to be able to sustain up to $80 \%$ and $73 \%$ of the ultimate load resistance for flexural and punching shear, respectively, in comparison to conventionally reinforced ribbed slab structure. The visual observation carried out during the experiment exhibited similar failure mode for both steel fibre reinforced and control samples. This was observed for both flexural and punching shear samples. Overall, it can be concluded that the steel fibres had displayed a promising potential to effectively replace the conventional reinforcements.
\end{abstract}

\section{Introduction}

Self-compacting concrete (SCC) has the ability to be properly poured in place, filling the formwork corners and small voids between reinforcement bars by means of its own weight without any compaction. Its rheological property allows SCC to be effectively applied in complex shaped elements and congested reinforcements [1-5]. The flow ability of SCC offers advantage to the construction process, whereas it could minimize the needs of skilled workers to work on concrete finishing. Nevertheless, this could lead to a reduction of costs as well as time needed to construct a structure [6].

* Corresponding author: hisbany@salam.uitm.edu.my 
In this research, steel fibres were being introduced to the SCC mix not only to reduce cracks but also as the only reinforcement in the slab structure. Steel fibre reinforced selfcompacting concrete (SFRSCC) is a relatively new composite material that combines the benefits of the self-compacting concrete (SCC) technology with the advantages derived from the fibre addition to a brittle cementitious matrix. SFRSCC combines the benefits of SCC at fresh state with high workability as well as its improvement of the properties at hardened state with addition of the steel fibres [7]. Steel fibres has the ability to improve the properties of SCC elements including tensile strength, ductility, toughness, energy absorption capacity [8], [9], fracture toughness [1], [10], [11] as well as cracking resistance [12]. Owing to the positive effects of steel fibres in enhancing the concrete materials properties especially by its contribution against crack propagation and enhancement in ductility, current research is now moving towards investigating the function of the fibres as the reinforcing material to partially or totally replace conventional reinforcements in concrete structures [13]. The aim of this paper is to investigate the flexural and punching shear behaviour of SFRSCC ribbed slab.

\section{Materials and mix composition}

For all experimental work carried out in this research, similar Grade 30 self-compacting concrete (SCC) composition was used as shown in Table 1. The SCC mix for the sample construction was produced in the concrete plant and delivered to the laboratory. The steel fibres were then manually added to the truck mixer at the end of the mixing process.

Hooked end steel fibres (Stahlcon HE 0.55/35) with the length, $1_{\mathrm{f}}=35 \mathrm{~mm}$, diameter of $\mathrm{d}=0.55 \mathrm{~mm}$ and aspect ratio $\left(\mathrm{L}_{\mathrm{f}} / \mathrm{d}_{\mathrm{f}}\right)$ of 65 was used in this study. The tensile strength of the steel fibre is $1250 \mathrm{~N} / \mathrm{mm}^{2}$. Hooked end steel fibres is chosen in order to enhance the anchorage between the steel fibre and the surrounding concrete matrix. The hooked end produces greater friction between the fibres and the aggregates in the matrix as compared to straight fibers [7] as well as higher toughness and residual strength [6],[15] as well as greater pull out forces [15]. Similar fibre dosage of $80 \mathrm{~kg} / \mathrm{m}^{3}$, which is equivalent to $1 \%$ of the total volume was used for the construction of all slab samples. This volume fraction was chosen based on findings from previous research [16]. The fibres are glued in bundles to facilitate the fibre distribution during concrete mixing and avoid the fibre balling effect [15], [17], [18]. This type of fibres conforms to the requirement of BS EN 14889-1 (2006).

Table 1. SCC Mix Composition.

\begin{tabular}{|c|c|c|c|c|c|c|}
\hline $\begin{array}{c}\text { Cement } \\
\text { CEM I } \\
42.5 \mathrm{R}\end{array}$ & $\begin{array}{c}\text { Pulverized } \\
\text { fly ash } \\
\text { (Class F) }\end{array}$ & $\begin{array}{c}\text { Coarse } \\
\text { aggregate } \\
(10 \mathrm{~mm})\end{array}$ & $\begin{array}{c}\text { Fine } \\
\text { aggregate }\end{array}$ & Water & w/c & $\begin{array}{c}\text { Steel fibre } \\
\text { content }\end{array}$ \\
\hline $315 \mathrm{~kg} / \mathrm{m}^{3}$ & $105 \mathrm{~kg} / \mathrm{m}^{3}$ & $830 \mathrm{~kg} / \mathrm{m}^{3}$ & $865 \mathrm{~kg} / \mathrm{m}^{3}$ & $185 \mathrm{~kg} / \mathrm{m}^{3}$ & 0.44 & $80 \mathrm{~kg} / \mathrm{m}^{3}$ \\
\hline
\end{tabular}

\section{Size of sample}

Four (4) ribbed slab samples were cast in the Heavy Structures Laboratory, Universiti Teknologi MARA (Malaysia). No vibration was applied to the self-compacting concrete mix during casting of the samples. The details of the samples were as shown in Table 2. The dimension of the ribbed slab samples was kept constant with $2.8 \mathrm{~m}$ (length) $\times 1.2 \mathrm{~m}$ (width) with the total slab thickness of $0.2 \mathrm{~m}$ considering the common size of precast slabs produced in the construction industry. The structural topping for all ribbed slab samples were fixed to $100 \mathrm{~mm}$. The cross-sectional details of the slabs are shown in Fig. 1. 
Table 2. Sample details.

\begin{tabular}{|c|c|c|}
\hline Designation & Reinforcement & Testing \\
\hline CRC(F) & Conventional & Flexural (four point bending) \\
\hline CRC(P) & Conventional & Punching shear \\
\hline SFWS(F) & Full steel fibres & Flexural (four point bending) \\
\hline SFWS(P) & Full steel fibres & Punching shear \\
\hline
\end{tabular}

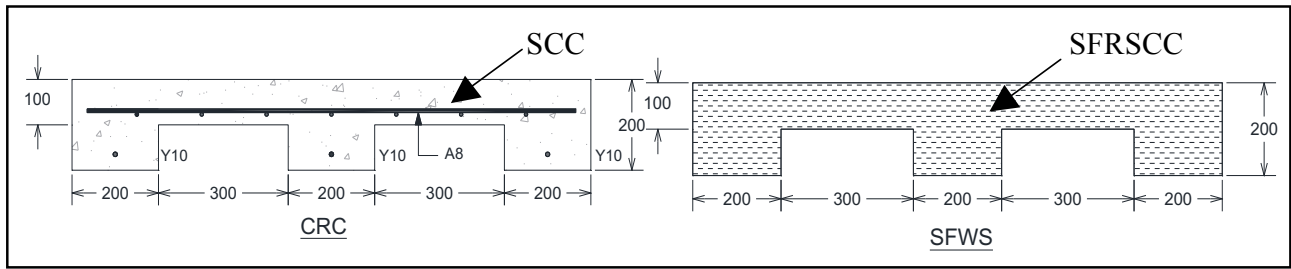

Fig. 1. Cross-sectional details of the ribbed slab sample.

After 28 days of sample curing using the wet gunny sacks, all samples were painted in white to ease the observation of the crack propagation pattern during the commencement of the testing. The measuring instruments involved for the experimental test: (1) linear variable displacement transducers (LVDT) to measure the vertical deflection of the slab samples and (2) Load cell to measure the loads from the actuator. The locations of the LVDT's for the flexural and punching shear test are shown in Fig. 4.

\section{Experimental setup}

The experimental work for this study consist of two experimental testing; flexural four point bending test and punching shear test. Fig. 2 shows the experimental setup for the flexural test. Four point bending was selected to permit slow gradual failure of the sample. The loading was applied by a hydraulic actuator through longitudinal spreader beam and two transverse loading rollers placed equidistance from the support in accordance to the guidelines given in the BS 12390-5 [20] under static load. The loading rate was set to a constant rate of $0.01 \mathrm{~mm} / \mathrm{sec}$ in order to be able to meticulously observe the crack pattern and failure mode that takes place during the loading.



Fig. 2. Flexural testing experimental setup. 
The experimental setup for the punching shear test is shown in Fig. 3. The punching load was subjected to the centre of the ribbed slab sample using a hydraulic jack controlled by a load cell at a constant rate of $0.01 \mathrm{~mm} / \mathrm{sec}$. The cross-sectional dimension of the column applied was $200 \times 200 \mathrm{~mm}$ to induce sufficient punching shear to the slab sample. The support was fixed to $1.2 \times 1.2 \mathrm{~m}$ focusing only on the centre of the ribbed slab sample.

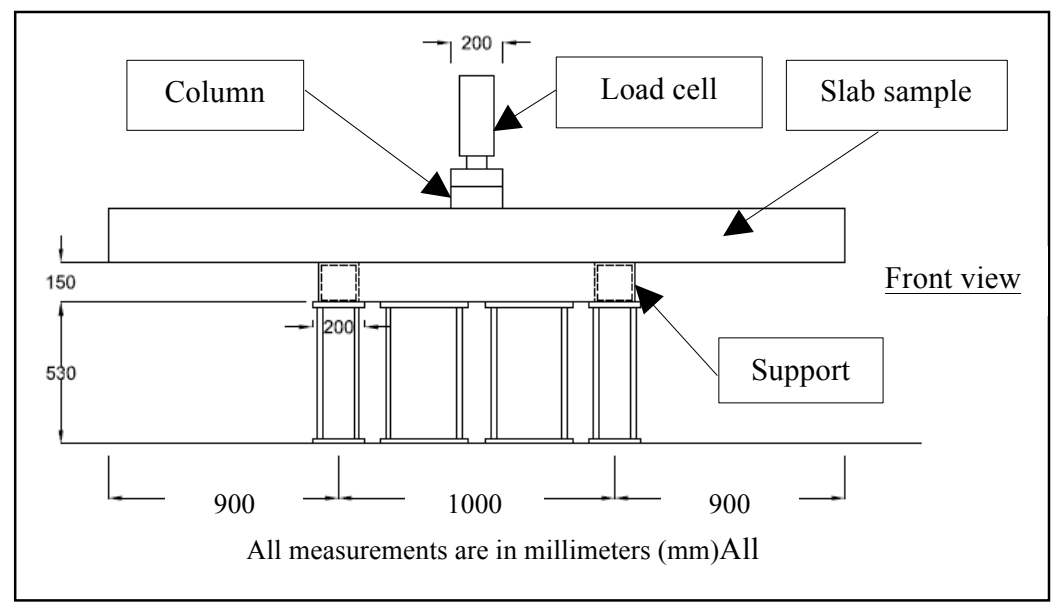

Fig. 3. Punching shear test experimental setup.

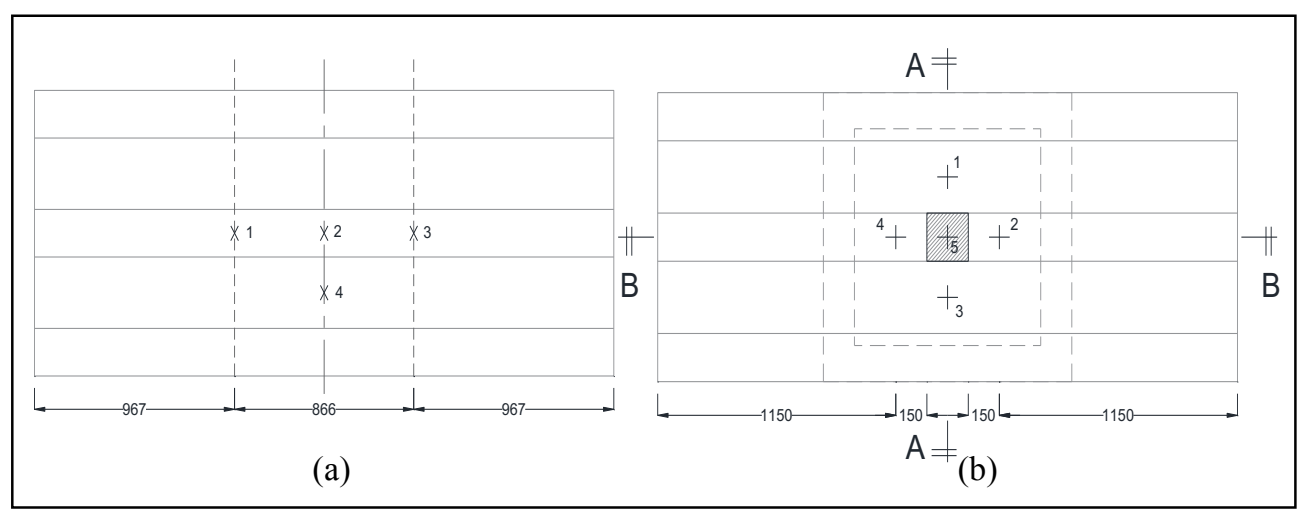

Fig. 4. LVDT locations (a) Flexural test (b) Punching shear test.

\section{Flexural testing results and discussion}

\subsection{First crack and ultimate load}

Table 3 presented the results from the flexural four point bending test. The presence of the steel fibres in the self-compacting concrete (SCC) significantly influence the first crack occurrence of the SFWS slab samples. In comparison between the CRC(F) and SFWS(F) samples, it can be observed that the SFWS(F) that is fully reinforced with steel fibres, had experienced crack at later stage and able to resist higher loads before crack is initiated as compared to samples that are conventionally reinforced $(\mathrm{CRC}(\mathrm{F}))$. This result proves the ability of the steel fibers to delay first cracks formation by enabling stress transfer across the cracks [21,22]. The values of the loads at first crack occurrence are shown in Table 3. The first crack load for the SFWS(F) sample is $47.67 \mathrm{kN}$ while for the $\mathrm{CRC}(\mathrm{F})$ sample is 
$21.39 \mathrm{kN}$, with indicated approximately $50 \%$ difference. As for the ultimate loading value, the SFWS(F) value was found to be slightly lower than the CRC(F) sample by approximately $20 \%$.

Table 3. Flexural test results.

\begin{tabular}{|c|c|c|c|c|c|}
\hline $\begin{array}{c}\text { Sample } \\
\text { designation }\end{array}$ & $\begin{array}{c}\text { Topping } \\
\text { thickness } \\
(\mathrm{mm})\end{array}$ & $\begin{array}{c}\text { First crack } \\
\text { load }(\mathrm{kN})\end{array}$ & $\begin{array}{c}\text { Ultimate load } \\
(\mathrm{kN})\end{array}$ & $\begin{array}{c}\text { Deflection at } \\
\text { design load } \\
(\mathrm{mm})\end{array}$ & $\begin{array}{c}\text { Deflection at } \\
\text { ultimate load } \\
(\mathrm{mm})\end{array}$ \\
\hline CRC(F) & 100 & 21.39 & 74.93 & 5.03 & 63.92 \\
\hline SFWS(F) & 100 & 47.67 & 60.00 & 1.27 & 7.8 \\
\hline
\end{tabular}

\subsection{Deflection of the samples}

The maximum deflection at the ultimate load was recorded by the LVDT at location L2 which was placed at the middle rib soffit. As specified in the Eurocode2 [23], in general, the deflection of a slab should not exceed span/250 in order to avoid damages to the appearance and general utilities of the structure. Furthermore, in order to avoid damages to non-structural members that is supported by the structure, partition walls for instance, the deflection after construction is limited to span/500. In this study, considering the $2.6 \mathrm{~m}$ effective span length of the ribbed slab sample, the allowable deflection is $5.2 \mathrm{~mm}$. Table 3 shows the deflection values recorded at design and ultimate load. At the design load of the ribbed slab sample, which is $31.49 \mathrm{kN}$ (determined from the theoretical calculation), it can be observed that the deflection value for the SFWS(F) sample is $1.27 \mathrm{~mm}$ which is lower than $\mathrm{CRC}(\mathrm{F})$. This deflection values are acceptable since it is within the limiting value stated in the requirement of the Eurocode2 [23]. These experimental results revealed that both samples has performed accordingly as per designed.

Table 3 also shows deflection values samples at ultimate loading. Comparing these values, it can be observed that the deflection value for the SFWS(F) samples were significantly lower than the $\mathrm{CRC}(\mathrm{F})$ sample. Upon reaching the ultimate load, the deflection for the SFWS(F) sample showed only $7.8 \mathrm{~mm}$ deflection as compared to the $\mathrm{CRC}(\mathrm{F})$ sample that deflected up to $63.92 \mathrm{~mm}$. This result indicates that even though it is not conventionally reinforced, the SFWS samples were still able to sustain the loadings subjected by having the strong interaction between the steel fibres in transferring the stresses effectively even after crack happens. Furthermore, the results also revealed that in terms of deflection at the ultimate load, the SFWS samples has the capability to perform better than the CRC samples. The steel fibres in the concrete mix has functioned effectively in holding the hardened concrete matrix together even after extensive cracking under flexural loading whereas it demonstrates the post-cracking ductility [22].

\subsection{Crack pattern and failure mode}

Visual observations were being carried out to identify the crack pattern and failure mode of the ribbed slab samples. In general, both types of samples, CRC(F) and SFWS(F) showed almost similar crack pattern at ultimate load, whereas both samples experienced minor cracks in the loading region. Fig. 5 showed the crack pattern of CRC(F) and SFWS(F) samples. The figures showed the side views and the bottom view of the ribbed slab samples at ultimate load. 


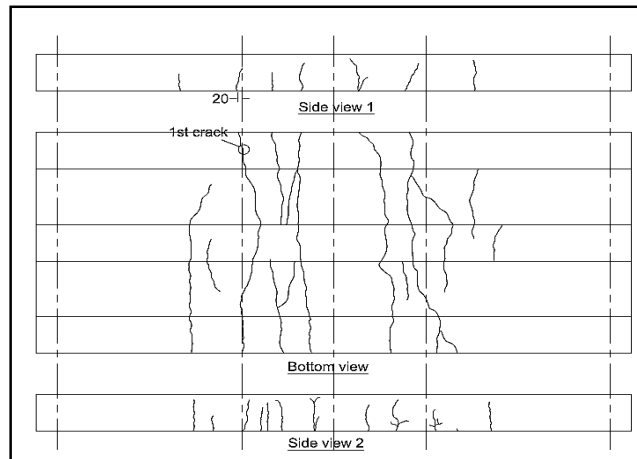

(a)

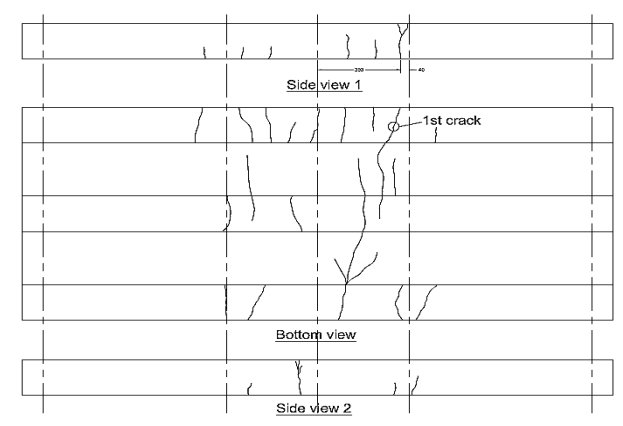

(b)

Fig. 5. Crack pattern (a) CRC(F) sample (b) SFWS(F) sample

Based on visual observation, the first crack of the CRC(F) sample occurred exactly under one of the loading line. This small $0.05 \mathrm{~mm}$ width crack was detected at the external rib soffit, $433 \mathrm{~mm}$ from the centre line. As the loading continues, one major crack formed near the centre line of the slab sample. The flexural behaviour of the $\mathrm{CRC}(\mathrm{F})$ slab samples meets the typical behaviour of reinforced concrete structures. The reinforcements in the CRC(F) slab samples was designed to carry the tensile forces transferred by the bonding at the interface of the two materials [24]. The failure mode exhibits gradual yielding of the tension steel reinforcements provided in the rib section.

The crack pattern of the SFWS(F) was almost similar to the CRC(F) samples whereas minor cracks were generated across the centre region of the slab. The first crack was initiated at the external rib, $393 \mathrm{~mm}$ from the centre line. As shown in Fig. 5, minor cracks was distributed evenly across the central region of this slab sample. At ultimate load, most of the cracks occurred only on the internal and external rib soffit. Only very small crack lines was observed propagating to the topping of the slab at this stage. A major crack was observed when the slab reached total failure, crossing from near the centre line towards the loading line. Based on the crack pattern and failure mode of the SFWS(F) sample, the explanation that can be drawn is the tensile stress in the sample has been effectively distributed and transferred to the steel fibres that is scattered along the structure. This similar failure mode of the sample as compared to the control sample has proven its ability to sustain flexural load in a similar ductile manner without abrupt failure.

\section{Punching shear test results and discussion}

\subsection{First crack and ultimate load}

This section discussed the punching test results. Similarly to the flexural test, observation was been made to the sample to locate and record the first crack load. First crack of the control sample CRC(P) occurred underneath the sample at the column line at $57.06 \mathrm{kN}$. The crack then propagates to the soffit and continued to the sides of the adjacent external ribs. They were scattered in the punching shear region. The cracks at the top part of the sample occurred only at the perimeter of the column. The punching shear cone can be observed from the middle rib. After the occurrence of the first crack, the sample continued to be loaded until it reached the ultimate shear capacity of $187.13 \mathrm{kN}$. The crack pattern for this sample is shown in Fig. 6 (a). 
Fig. 6 (b) showed the crack pattern for the SFWS(P) sample. The first crack occured at $75 \mathrm{kN}$ load underneath the sample at the middle rib, right below the location of the loading column. The crack then elongates creating a $45^{\circ}$ angle towards the soffit and one of the adjacent ribs. The ultimate shear capacity for this sample was $135.68 \mathrm{kN}$.

In comparison of this two samples, it can be seen that the SFWS(P) that was fully reinforced with steel fibres was able to sustain slightly lower ultimate load than the conventionally reinforced sample $(\mathrm{CRC}(\mathrm{P}))$. The difference is approximately $27 \%$. Conversely, viewing at the ability of the samples to sustain loads before the initiation of the first crack, SFWS(P) was found to perform better with almost $31 \%$ higher load than $\mathrm{CRC}(\mathrm{P})$. This might be due to small spacing between the fibres, that allows it to effectively bridge cracks throughout the whole volume of the concrete structure, thus enhancing the integrity of the slab under the column loading point [25]. Additionally, adequate amount of steel fibres also assist in enhancing the tensile strength of the concrete matrix, resulting an increase in the punching shear force.

Comparing the crack pattern of the two samples, it can be observed that the cracks were scattered around the perimeter of the column and within the supported area. For the control sample, the cracks were more scattered displaying the effective distribution of the stresses across the punching shear region. The pattern of the crack was in combination of punchingflexural mode, whereas cracks occurred at the column face as well as extends radially from the column's corner to corners of the slab's support.

As for the SFWS(P) sample, the crack pattern showed crack lines along the sides of the middle rib supporting the column and extends towards the support. The pattern slightly indicates that the slab underwent flexural failure mode. However, attention should be taken in view of the weak region at the sides of the middle rib.

For the control sample, CRC(P) it can be observed that the concrete cover at the bottom of the slab was about to fall apart due to the brittleness of the concrete matrix. Whereas for the SFWS(P) sample, the cracks occurred on the bottom surface was more intact with smaller width. This is due to the bridging effect of the steel fibres that significantly improve the ductility and the integrity of the slab-column connection [26].

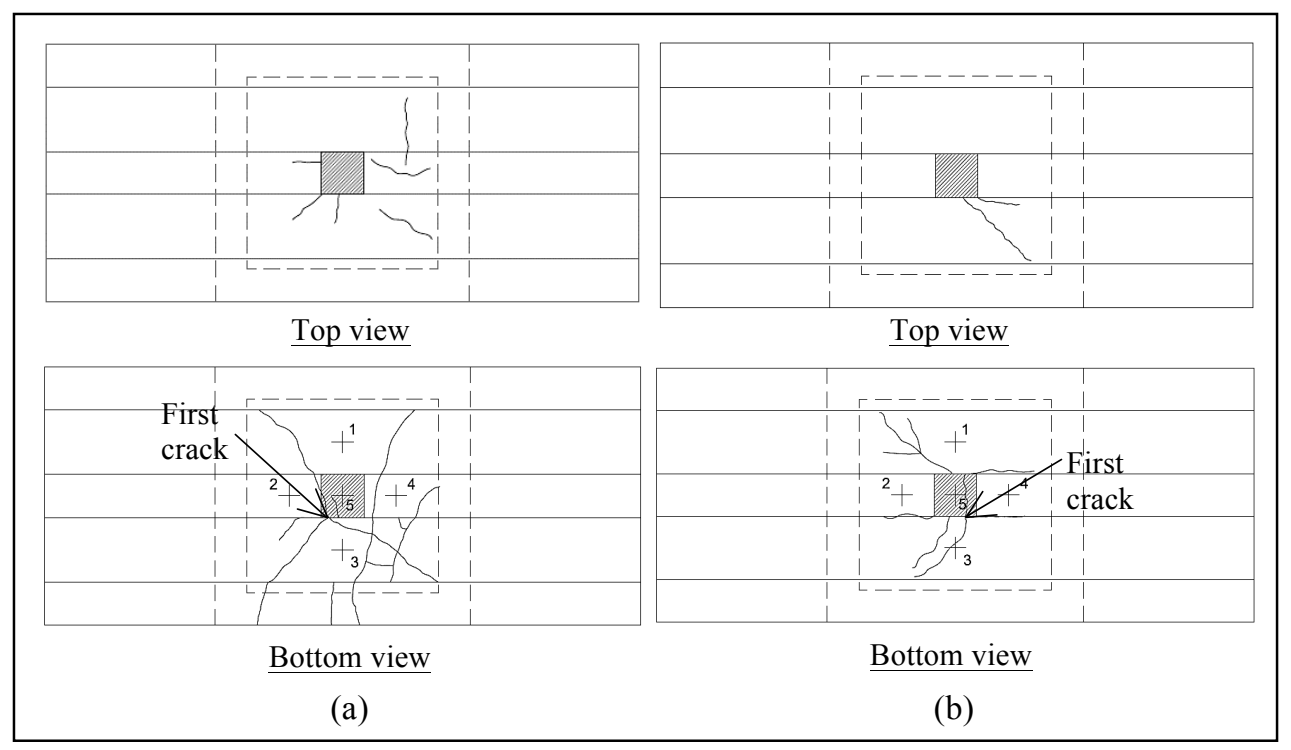

Fig. 6. Punching shear crack pattern (a) CRC(P) (b) SFWS (P). 


\subsection{Deflection}

Figures below presents the deflection profile of the ribbed slab sample recorded at the ultimate loading. The comparison of the deflection profile between the CRC(P) and SFWS(P) sample is shown in Fig. 7. The deflection profile were plotted based on the LVDT readings within the support area.

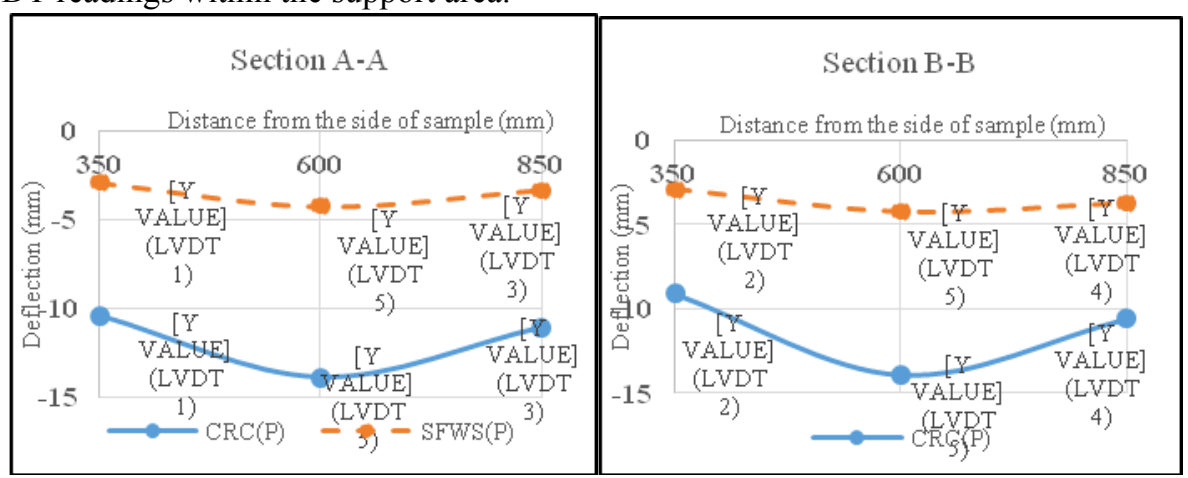

Fig. 7. Deflection profile of the samples at ultimate loading.

Based on the deflection profile, it can be observed that the deflection value for the CRC(P) sample was higher than the SFWS(P) sample. The maximum deflection value for both samples was recorded at the middle point where the load was located. The maximum value for the CRC(P) sample was $13.88 \mathrm{~mm}$ while for the SFWS(P) sample the value is $4.25 \mathrm{~mm}$, which is significantly lower. These readings has proven the effectiveness of the steel fibres that is included in the concrete matrix in improving the ductility of the slabcolumn connections by modifying the failure mode, from pure punching to flexural, that contributes significantly in the ultimate shear capacity [27].



Fig. 8. Load versus displacement of the punching shear samples.

Fig. 8 shows the load versus displacement curve for samples $\mathrm{CRC}(\mathrm{P})$ and $\mathrm{SFWS}(\mathrm{P})$. Similarly to the flexural behaviour of the ribbed slabs, at the first stage of loading, the graph is approximately linear. Upon crack initiation, the curve tends to move away from the straight line, exhibiting a decrease in the stiffness of the slab. In comparison of the two curves, it can be observed that the deflection value for the CRC(P) sample was higher than SFWS(P) at the same point of load. Beyond the ultimate shear value, the strength of the CRC(P) sample drastically dropped, causing sudden and loss in shear resistance exhibiting that the sample can no longer sustain the punching shear force. On the other hand, for the SFWS(P) sample, upon reaching the ultimate load, the graph gradually descends revealing that the steel fibres still contributes to the stress transfer even after the crack occurrence, showing proof on the enhancement of the structural ductility [27]. 


\section{Conclusion}

From the flexural test, it can be concluded that the SFWS sample performed better in terms of its first crack initiation and comparable with regards to its ultimate load. The performance of SFWS is also reflected in the deflection reading where it shows lower deflection in comparison to the $\mathrm{CRC}(\mathrm{F})$ sample and the reading was still within the Eurocode 2 limit. The crack pattern for both samples were found to be almost similar, experiencing minor cracks with no abrupt, brittle failure, exhibiting ductile behavior.

For the punching shear test, it can be concluded that similarly to the flexural testing results, the SFWS(P) sample was found to perform better in terms of the first crack initiation. However, the ultimate load was found to be $27 \%$ lower than conventional sample. In view of the failure mode, the $\mathrm{CRC}(\mathrm{P})$ sample underwent punching-flexural mode with brittle cracks on the bottom surface while the SFWS(P) experienced flexural failure mode. The displacement of the SFWS(P) sample was lower as compared to the CRC(P) sample.

As a whole, it can be concluded that the ribbed slab sample (SFWS) has the ability to perform well under both flexural and punching shear. However, special attention should be taken under punching shear since the SFWS(P) sample exhibited failure due to the geometrical aspect of the structure.

Special thanks to laboratory staffs of the Faculty of Civil Engineering, Universiti Teknologi MARA, Malaysia for their help and technical support. Also gratitude to MOSTI for the project funding under E-Science Fund (06-01-01-SF0835) and also the Institute of Research Management \& Innovation (IRMI), Universiti Teknologi MARA for their continuous support.

\section{References}

1. P. L. Domone, "A review of the hardened mechanical properties of self-compacting concrete," Cem. Concr. Compos., 29, 1, pp. 1-12 (2007)

2. Y. Fritih, T. Vidal, A. Turatsinze, and G. Pons, "Flexural and shear behavior of steel fiber reinforced SCC beams," KSCE J. Civ. Eng., 17, 6, pp. 1383-1393 (2013)

3. A. Khaloo, E. R. Molaei, P. Hosseini, and H. Tahsiri, "Mechanical performance of self-compacting concrete reinforced with steel fibers," Constr. Build. Mater., 51, pp. 179-186 (2014)

4. H. Okamura and M. Ouchi, "Self-Compacting Concrete," J. Adv. Concr. Technol., 1, 1, pp. 5-15 (2003)

5. L. Ferrara and A. Meda, "Relationships between fibre distribution, workability and the mechanical properties of SFRC applied to precast roof elements," Mater. Struct., 39, pp. 411-420 (2007)

6. M. Pająk and T. Ponikiewski, "Flexural behavior of self-compacting concrete reinforced with different types of steel fibers", Constr. Build. Mater., 47, pp. 397-408 (2013)

7. S. Grunewald, Performance-based design of self-compacting fibre reinforced concrete. Delft University Press (2004)

8. S. Grunewald and J. C. Walraven, "Transporting fibres as reinforcement in selfcompacting concrete," Heron, 54, 2-3, pp. 99-124 (2009)

9. A. Khaloo and M. Afshari, "Flexural behaviour of small steel fibre reinforced concrete slabs," Cem. Concr. Compos., 27, 1, pp. 141-149 (2005) 
10. B. Akcay and M. A. Tasdemir, "Mechanical behaviour and fibre dispersion of hybrid steel fibre reinforced self-compacting concrete," Constr. Build. Mater., 28, 1, pp. 287293 (2012)

11. A. S. El-Dieb, "Mechanical, durability and microstructural characteristics of ultrahigh-strength self-compacting concrete incorporating steel fibers," Mater. Des., 30, 10, pp. 4286-4292, (2009)

12. F. Aslani, S. Nejadi, and B. Samali, "Short term bond shear stress and cracking control of reinforced self-compacting concrete one way slabs under flexural loading," Comput. Concr., 13, 6, pp. 709-737 (2014)

13. J. Michels, D. Waldmann, S. Maas, and A. Zürbes, "Steel fibers as only reinforcement for flat slab construction - Experimental investigation and design," Constr. Build. Mater., 26, 1, pp. 145-155 (2012)

14. D. V. Soulioti, N. M. Barkoula, A. Paipetis, and T. E. Matikas, "Effects of Fibre Geometry and Volume Fraction on the Flexural Behaviour of Steel - Fibre Reinforced Concrete Effects of Fibre Geometry and Volume Fraction on the Flexural Behaviour of Steel-Fibre Reinforced Concrete," Strain, 47, pp. 535-541 (2011)

15. A. A. Shah and Y. Ribakov, "Recent trends in steel fibered high-strength concrete," Mater. Des., 32, 8-9, pp. 4122-4151 (2011)

16. N. N. Sarbini, I. S. Ibrahim, and A. A. Saim, "Assessment on the Mechanical Performance of Steel Fibre Reinforced Concrete using Fibres Geometrical Factor," BEFIB2012-Fibre Reinf. Concr., (2012)

17. N. A. Rahman, S. H. Hamzah, and A. Abdulrazzaq, "Effectiveness of SteFib in Composite Structural Member," J. Eng. Sci. Technol., 7, 5, pp. 552-562 (2012)

18. Z. Tazaly, "Punching Shear Capacity of Fibre Reinforced Concrete Slabs with Conventional Reinforcement," Royal Institute of Technology (KTH) (2011)

19. BS EN 14889-1, "Fibres for concrete: Part 1: Steel fibres - Definitions, specifications and conformity." European Committee for Standardization (CEN), Brussels (2006)

20. BS EN 12390-5, "Testing hardened concrete - Part 5: Flexural strength of test specimens.” European Committee for Standardization (CEN), Brussels (2009)

21. R. N. Swamy, "FRC for Sustainable Infrastructure Regeneration and Rehabilitation," in Fifth International RILEM Symposium on Fibre-Reinforced Concrete (FRC), pp. 319 (2000)

22. J. Narwal, A. Goel, D. Sharma, D. R. Kapoor, and B. Singh, "An Experimental Investigation on Structural Performance of Steel Fibre Reinforced Concrete Beam," Int. J. Eng. Adv. Technol., 2, 6, pp. 301-304 (2013)

23. MS EN 1992-1-1, "Eurocode 2: Design of Concrete Structures - Part 1-1: General rules and rules for buildings." Department of Standards Malaysia (2010)

24. B. Mosley, J. Bungey, and R. Hulse, Reinforced Concrete Design to Eurocode 2, 7th ed. London: Palgrave Macmillan (2012)

25. L. Nguyen-minh, M. Rov, and T. Tran-quoc, "Punching Shear Capacity of Interior SFRC Slab-Column Connections," J. Struct. Eng., 138, pp. 613-624 (2012)

26. L. Nguyen-Minh, M. Rovňák, T. Tran-Quoc, and K. Nguyenkim, "Punching Shear Resistance of Steel Fiber Reinforced Concrete Flat Slabs," Procedia Eng., 14, pp. 1830-1837 (2011)

27. M. H. Harajli, D. Maalouf, and H. Khatib, "Effect of Fibers on the Punching Shear Strength of Slab-Column Connections," Cem. Concr. Compos., 17, pp. 161-170, (1995). 